\title{
YELLOW BIRCH REGENERATION ON SCARIFIED SEEDBEDS UNDER SMALL CANOPY OPENINGS
}

\author{
By R. J. HATCHER ${ }^{1}$
}

R. J. Hatcher completed his primary education in Montreal and received his B.Sc.F. degree from the University of New Brunswick in 1953. Since graduation he has been employed by the Federal Government, initially at the Valcartier Forest Experiment Station in the fields of forest growth, yield, and management, and latterly at the Forest Research Laboratory, Ste. Foy, Quebec, where he has conducted research into the problems of forest regeneration.

\section{ABSTRACT}

Four years after establishment, an experiment in regenerating yellow birch (Betula alleghaniensis Britt.) on prepared seedbeds under one-tenth and onequarter acre circular canopy openings created by cutting and girdling trees in a deteriorated tolerant hardwood stand indicates that all combinations of method and size resulted in satisfactory birch stocking. Yellow birch outgrew its principal competitor sugar maple (Acer saccharum Marsh.), underbrush competition has not jeopardized good birch survival, and deer browsing has been low.

\section{RESUME}

En vue d'étudier la régénération du bouleau jaune (Betula alleghaniensis Britt.) sur des lits de germination préparés, des trouées de forme circulaire de $1 / 10$ et 1/4 d'acre ont été pratiquées à l'aide de coupe et annelage dans un peuplement détérioré de feuillus tolérants. Quatre ans après le début de l'expérience le taux de germination du bouleau jaune était jugé satisfaisant pour toutes les combinaisons de méthodes employées et de dimensions des trouées. Le bouleau jaune a surpassé en croissance son principal compétiteur l'érable à sucre (Acer saccharum Marsh.), sa survivance n'a jamais été mise en péril par la competition de la strate arbustive et l'intensité du broutage par le chevreuil a été bas.

\section{INTRODUCTION}

An experiment at Valcartier, Quebec, to test practical methods of overcoming the difficulty in regenerating yellow birch (Betula alleghaniensis Britt.) in deteriorated tolerant hardwood stands shows, four years following establishment, that the methods tested have been reasonably successful. The study was made in the Acereto-Betuletum forest association (Jurdant ${ }^{2}$ ) a hardwood forest composed of yellow birch, sugar maple (Acer saccharum Marsh.) and beech (Fagus grandifolia Ehrh.) that occupies some of the potentially richest woodproducing forest land in Quebec.

Such an association of long-lived and tolerant species might be considered an ideal forest in which to apply a selection method of silviculture, or some

\footnotetext{
${ }^{I}$ Research Scientist, Department of Forestry of Canada, Quebec Region.

Jurdant, M. 1959. Ecological classification of the forest stands of the Eastern Townships, Great Lakes - St. Lawrence Region, Quebec. Canada, Dept. Northern Affairs and National Resources, For. Br. Binder 1711. (unpublished).
} 
form of light partial cutting on a short cutting cycle. However, in such systems regeneration must develop under the shade of residual trees. Unfortunately, yellow birch is the least shade-tolerant of the three species and least likely to succeed under a selection system while at the same time it is at present of higher commercial value than maple and beech.

The methods tested are not unconditionally recommended but results presented hereafter suggest that they could be successfully applied in similar stands elsewhere to provide a desirable proportion of yellow birch in future stands.

\section{Study Area Description}

The experiment was conducted in a stand of 63 acres at the Valcartier Forest Experiment Station $\left(71^{\circ} 30^{\prime} \mathrm{W}, 46^{\circ} 57^{\prime} \mathrm{N}\right), 20$ miles north of Quebec in the Laurentian Section of the Great Lakes St. Lawrence Forest Region (Rowe, 1959). The stand, on an east-facing slope of a 1400 -foot mountain, has a range in elevation above sea level from 1000 to 1200 feet and a slope variation from $5^{\circ}$ to $50^{\circ}$.

The brown podzolic soil is a bouldery, very stony silty sand of glacial till origin with some colluvium mixing. In general, it is a thin mantle up to two feet thick covering granite gneiss bedrock, and because of seepage would be classed as only moderately well drained. With such characteristics, it would tend to become dry quickly in periods of drought, and saturated soon after the onset of rain.

Annual precipitation at Valcartier is 49 inches (19 year average 1946-64), comprising 38 inches of rain and 112 inches of snow. About 47 per cent or 23 inches of the total is recorded as rain from May to September. Average numbers of days with rainfall during the most critical months for seedling survival, May and June, are 12 and 13 days respectively. Average daily temperatures for June, July and August are $59^{\circ} \mathrm{F}, 64^{\circ} \mathrm{F}$, and $61^{\circ} \mathrm{F}$.

The stand was composed mainly of sugar maple, yellow birch and beech in the proportions of 61,21 and 16 percent by basal area. Very small numbers of red maple (Acer rubrum L.), white birch (Betula papyrifera Marsh.), trembling aspen (Populus tremuloides Michx.), pin cherry (Prunus pennsylvanica L.f.), red spruce (Picea rubens Sarg.), balsam fir (Abies balsamea (L.) Mill.) and hemlock (Tsuga canadensis (L.) Carr.) completed the stand. Sugar maple was the only species represented in most diameter classes from one to 20 inches dbh., even though the majority of trees were mature or overmature. Small diameter trees of all species were concentrated in patches under canopy openings provided by past logging. Beech was poorly represented in sapling and pole-size classes and yellow birch was conspicuously absent from diameter classes below 10 inches.

By 1959 almost all high-quality veneer logs and sawlogs plus small amounts of fuelwood, had been logged. Most residual trees above eight inches dbh. were defective and of little immediate or potential value except as fuelwood. Some yellow birch became established following logging but apparently could not survive beyond the sapling stage in circumstances of maple competition and diminishing light as canopy holes closed.

The principal ground cover species was sugar maple and while underbrush density was variable, in general it was not dense. Most abundant species were 
mountain maple (Acer spicatum Lam.) striped maple (Acer pensylvanicum L.) and Dryopteris spp.

\section{Treatment}

\section{EXPERIMENTAL METHOD}

The failure of yellow birch to regenerate and develop adequately following logging operations in eastern Canada, where sugar maple and beech are common associates, is ascribed to unfavourable seedbeds of thick litter and inadequate light (Jarvis, 1956). A source of seed is not usually lacking.

Many methods have been assessed for suitability in regenerating yellow birch, including soil disking (Godman, 1957) litter burning (Holowacz, 1960), bulldozer scarification (Drinkwater ${ }^{3}$; Fayle ${ }^{4}$; Wang, 1964), scarification plus tree girdling (Fayle ${ }^{5}$; Jarvis, 1957), uniform partial cutting and clear cutting (Barrett et al, 1962, Linteau, 1948), and creating small stand openings (Gilbert and Jensen, 1958; Jensen, 1950; Linteau, 1948; Leak and Wilson, 1958; Zillgitt and Eyre, 1945). The creation of small canopy openings was judged by the author to be the most promising technique because of the probable advantages of more stable light conditions, less desiccation of seedbeds and lesser amounts of competing vegetation.

A factorial experiment was laid out to test two sizes of circular stand openings and two methods of providing these openings. The four combinations of factors were assigned at random to plots within each of four replications. Thus each replication comprised four circular plots:

1) $1 / 10$-acre, trees cut and removed

2) $1 / 10$-acre, trees girdled

3) 1/4-acre, trees cut and removed

4) 1/4-acre, trees girdled

A minimum distance of three chains between plot centres was maintained.

Stand treatment began July 14, 1960, and was completed by mid-August. Trees were girdled with chain saws with cuts made one to three inches into the wood. Trees larger than seven inches dbh were ringed twice with three to five inches between cuts. Wood and slash from cut plots were piled off the plots.

In early September, ten one-milacre random quadrats $\left(6.6^{\prime} \times 6.6^{\prime}\right)$ were established in each of the sixteen plots. Leaf litter and ground vegetation were scraped from the quadrats with garden rakes. This treatment loosened the humus but only occasionally was there any mixing of humus and mineral soil.

In mid-October, five quadrats of the ten on each plot were seeded artificially, each with three-quarter ounces of yellow birch seed collected from trees felled on cut plots. About $80-90$ per cent of the 1960 leaf fall had occurred by this time, and these leaves were carefully raked off the

${ }^{8}$ Drinkwater, M. M. 1959. Seedbed preparation to improve the stocking of yellow birch in a tolerant hardwood stand, Pictou County, Nova Scotia. Canada, Dept. Northern Affairs and National Resources, For. Br. Binder 1712 (unpublished).

"Fayle, D. C. F. 1958a. Cutting and seedbed preparation to improve the stocking to yellow birch in tolerant hardwood stands. Eyre and Havelock Townships, Haliburton County, Ontario. Canada, Dept. Northern Affairs and National Resources, For. Br. Binder 1511 (unpublished).

${ }^{5}$ Fayle, D. C. F. 1958b. Girdling and seedbed preparation to improve the stocking of yellow birch in cut-over tolerant hardwood stands, Guilford Township, Haliburton County, Ontario. Canada, Dept. Northern Affairs and National Resources, For. Br. Binder 1494 (unpublished). 
prepared seedbeds before the seed was hand-scattered. At the same time, this leaf fall was removed from quadrats to be naturally seeded in two of the four replications.

In late October 1961, five additional quadrats per plot were established. These quadrats do not represent a true repetition of the natural seeding half of the original experiment but provide a comparison of birch stocking and growth on seedbeds prepared one and two seasons following stand treatment.

\section{Field Measurements}

Quadrats established in 1960 were assessed in the autumns of 1961 and 1963; 1961 quadrats were assessed in 1962 and 1964. For each quadrat at each assessment, heights of the tallest yellow birch and sugar maple seedling were recorded, along with total number of seedlings of all tree species (pin cherry was classed as a shrub) on one-quarter of the milacre. Although red maple, white birch, beech, aspen, balsam fir and red spruce were encountered, their representation was so small that they are not discussed further. An ocular estimate was made of per cent cover for all herbs and shrubs.

\section{Method of Analysis}

Data analysis consisted of 12 analyses of variance for yellow birch maximum seedling heights and seedling numbers followed by Duncan's New Multiple Range Test for significance of differences between means at the five percent level. Significances of differences between mean maximum seedling heights of birch and maple were tested using the $t$ test for paired samples at both one and five per cent levels. Tests were not considered necessary to confirm the significance of the large differences in seedling numbers between birch and maple. Average per cent cover values for herbs and shrubs were compiled for 1963 and 1964 estimates.

\section{Results}

No unusual weather phenomena were recorded during the study. Annual precipitation from 1960 to 1964 averaged 46 inches, three inches less than the 19 year average. Number of days with rainfall during the critical months of May and June were 14 and 17 days respectively in 1961 and 11 days each in 1962.

The only observable effect of tree girdling in 1960 was a slight leaf wilting on some small trees in early September. Almost all girdled trees leafed out in May 1961 but leaf size throughout the summer was smaller than normal, and color began to change and leaves fell two weeks earlier than normal. Less than one-half the trees leafed out in May 1962 and by mid-summer almost all were leafless.

Deer browsing was noted in 1963 on a few quadrats densely stocked with birch. Some of the tallest birch were not eaten; deer apparently preferred to keep their heads down at the 6-12" level where foliage was dense. Seedlings were not eaten to ground level and the total effect to this feeding was negligible.

All combinations of size and method of canopy opening have provided satisfactory yellow birch regeneration three years after stand treatment on both seeded and unseeded quadrats. Only three milacres out of 240 were without a birch seedling. Mean maximum seedling height of this species varied from 20.5 to 51.2 inches (Table 1), and these seedlings outgrew their maple counterparts (Table 4). The tallest birch exceeded in height the tallest maple 
TABLE 1

Mean Maximum Yellow Birch Seedling Heights, by Treatment and Year (FOR A GIVEN MEASUREMENT, ANY TWO MEANS NOT UNDERSCORED BY THE SAMB LINE ARE SIGNIFICANTLY DIFFERENT AT THE 5\% LEVEL)

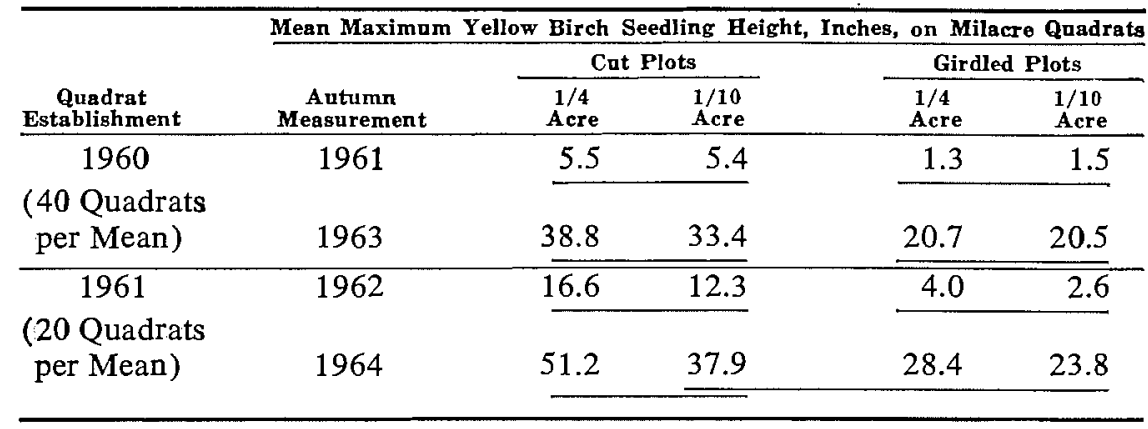

on 83 per cent of quadrats in cut plots and on 68 per cent in girdled plots.

Examination of treatment effects on yellow birch indicates that initial height growth on cut plots was superior to that on girdled plots, but once the girdled trees began to die, the rate of seedling height growth increased rapidly (Table 1). Possibly quarter-acre canopy openings were slightly more favorable for height growth than tenth-acres but statistical testing revealed no significant differences.

On quadrats established in 1960, an excellent yellow birch seed year, vast numbers of birch survived the summer of 1961 (Table 2). The smallest average

TABLE 2

Mean Numbers of Yellow Birch Seedlings by Treatment, Year and Method of SeEding

(FOR A GIVEN MEASUREMENT, ANY TWO MEANS NOT UNDERSCORED BY THE SAME LINE ARE SIGNIFICANTLY DIFFERENT AT THE 5\% LEVEL)

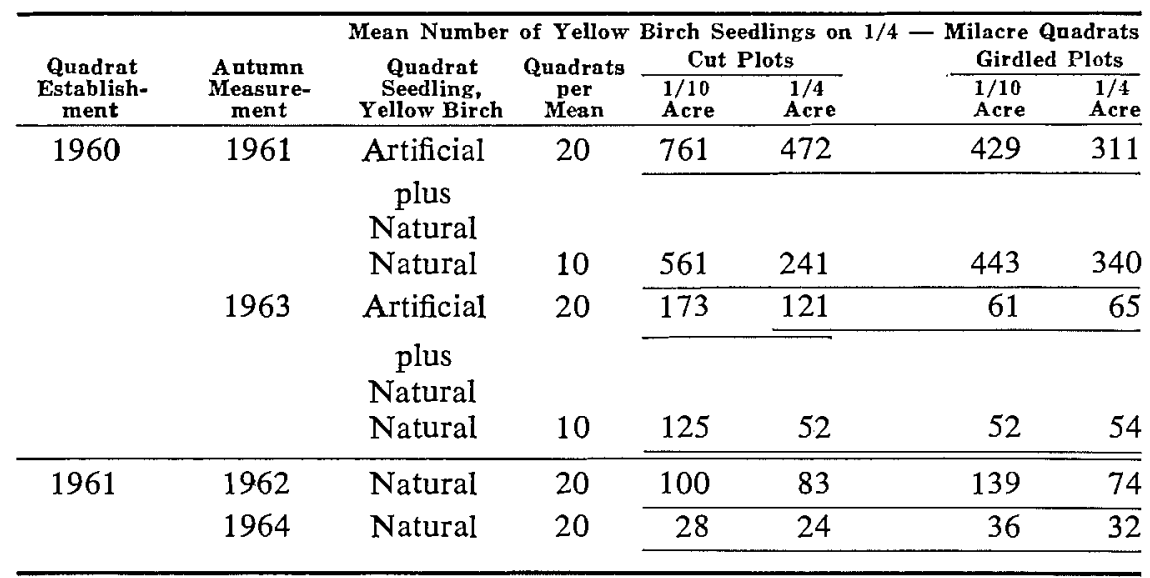


survival, on naturally seeded quarter-acre cut plots, was equivalent to a stocking density of 964,000 seedlings per acre. Byi autumn 1963, many seedlings had died but the lowest density still was equivalent to 208,000 birch per acre. In contrast to 1960,1961 was a poor seed year. This fact, plus the somewhat lower rainfall frequency in May and June, undoubtedly accounted for the much lower birch density on 1961 quadrats. Nevertheless, even after substantial mortality up to 1964 the lowest stocking (on quarter-acre cut plots, as in 1963) was equivalent to 96,000 stems per acre.

The scattering of three-quarter ounces or about 10,000 yellow birch seeds on half the quadrats in 1960 had remarkably little effect on total stocking by autumn 1961 (Table 3). None of the differences between treatment means for artificially and naturally seeded quadrats was statistically significant, although almost certainly the scattering of seed raised stocking levels slightly. The largest differences attributable to artificial seeding occurred on quarter-acre cut plots where natural seeding would be expected to have been lowest among the treatments.

The removal of the 1960 leaf fall from naturally seeded quadrats in midOctober on two replications of the experiment led to the important discovery that, where canopy openings were created by girdling, yellow birch stocking was 10 times that for quadrats where these leaves were not removed (Table 3).

Comparisons of mean maximum birch and maple seedling heights on 1960 quadrats show that birch receiving full light from above outgrew maple from the first growing season (Table 4). Logan (1965) and Fayle (1961) have reported substantially the same result over five-year periods in Ontario. Growth rates for birch seedlings comparable to those observed have been noted elsewhere (Anderson, 1964; Fayle, 1961; Wang, 1964; Winget ${ }^{6}$ )

'Winger, C. H. 1964. Silvical studies of yellow birch and associated species in Wisconsin. Univ. of Wisconsin, For. Dept. Ph.D. Thesis.

TABLE 3

Mean Numbers of Yellow Birch Seedlings One Year after Establishment, by Treatment, Method of Seeding, and Date of Litter Removal (FOR A GIVEN MEASUREMENT, ANY TWO MEANS NOT UNDERSCORED BY THE SAME LINE ARE SIGNIFICANTLY DIFFERENT AT THE 5\% LEVEL; FOR A GIVEN TREATMENT, ANY TWO MEANS SEPARATED BY AN ASTERISK $\left({ }^{*}\right)$ ARE SIGNIFICANTLY DIFFERENT AT THE 5\% LEVEL)

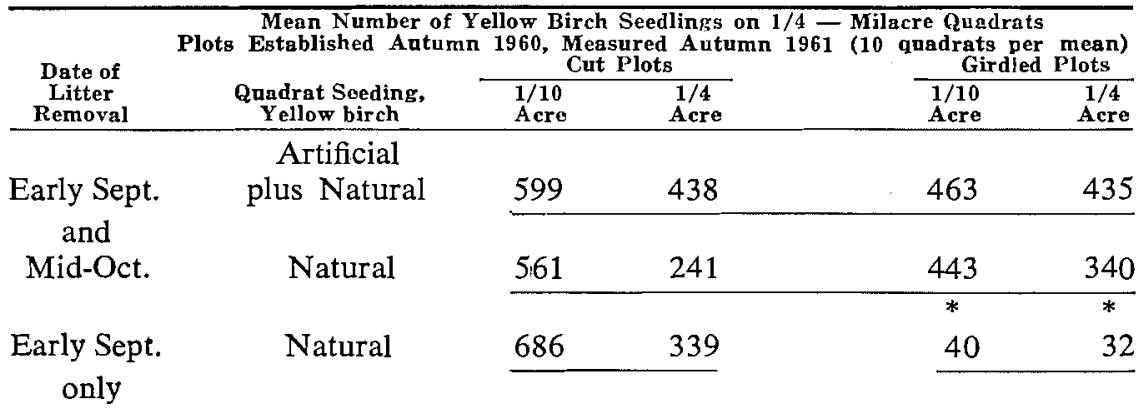


A surprising discovery is that both yellow birch and sugar maple mean maximum height for the first season's growth on 1960 quadrats were only onethird as large as corresponding heights for 1961 quadrats (Table 4). This difference between quadrats established the first and second year following stand treatment may be due to some changing soil factor or factors, to changes in above-ground conditions of light and competition, or to a combination of these factors.

The ratio of numbers of yellow birch to sugar maple dropped appreciably from the first to the third year following stand treatment (Table 5), and whereas birch on 1960 quadrats maintained a numerical lead over maple, the advantage was less impressive for 1961 quadrats. Original numbers of maple were similar for both years which suggests that maple seed production was relatively constant.

Disregarding the relatively unimportant herbs, raspberry (Rubus Idaeus L.) and pin cherry occurred more frequently than other shrubs three years after treatment. These two species provided the only important shrub competition to yellow birch for available light and were denser on cut than girdled plots.

On several quadrats in cut plots, pin cherry was the tallest stem but careful examination did not reveal that yellow birch was being seriously suppressed as a consequence. Where raspberry was particularly dense, the flattening of canes over winter resulted in suppression of birch but the numerical dominance of birch is such that little doubt exists of its capacity to overcome this competition within two or three years.

\section{DISCUSSION}

The scope of this experiment did not include all sites, aspects or climates where yellow birch is an important stand component, and thus the treatments cannot be universally recommended. However, the methods which have proved successful in regenerating yellow birch at Valcartier could probably be successfully applied on similar sites over much of this species' range, with the following qualifications kept in mind:

1) On south and southwest slopes it might be wise to limit the canopy opening produced by logging to a tenth-acre in order to reduce possible danger of temperature extremes and site desiccation.

2) Removal of litter in seedbed preparation must be done after the current year's leaves have fallen with a possible but not recommended exception of quarter-acre logged plots where such leaf fall would be moderate.

3) Where the surrounding forest contains several sexually mature yellow birch per acre, artificial seeding is probably not required. Should a complete seed crop failure occur, a one-year delay in regeneration would ensue but seedbeds could be re-established at far less cost than artificial seeding.

4) From observations in neighbouring stands that were heavily logged, the author feels that in most stands, and particularly those on exposed south slopes where quarter acres are to be logged, the preparation of many small scarified seedbeds is recommended over any form of uniform scarification. Better 
DECEMBER, 1966

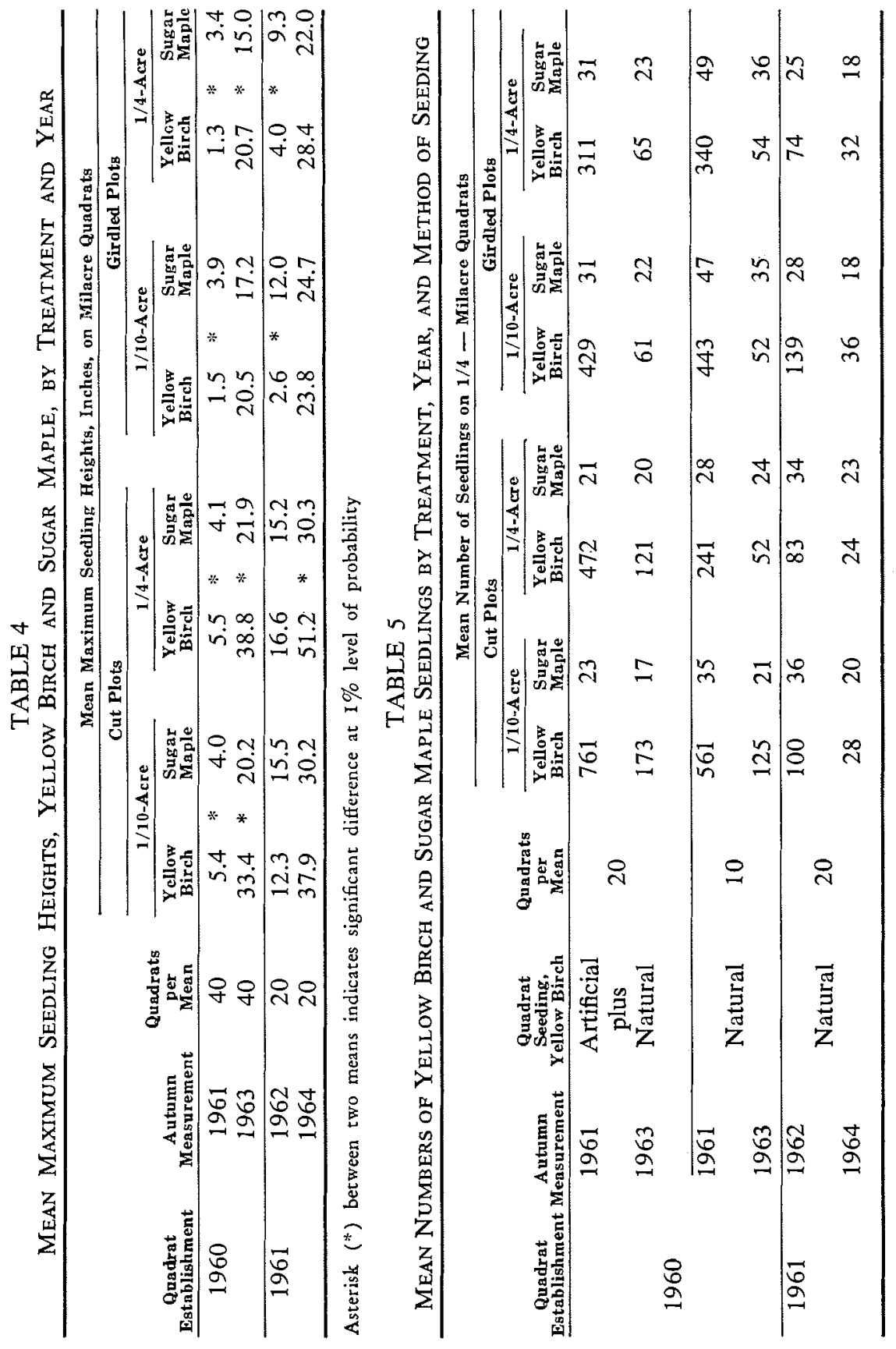


control over seedling distribution and density would probably be achieved and evaporation from the soil, and underbrush density, would be lower.

5) There is certainly no advantage in girdling when low-quality hardwoods from cut plots can be profitably used or sold. Where such utilization is impossible, then girdling has the advantage of lower cost.

6) Stand openings smaller than tenth-acres would probably close too rapidly to permit good birch development beyond the seedling stage. Openings larger than one-quarter acre might be suitable in some circumstances but the multiple risk of increased shrub competition, greater seedbed desiccation and less natural seeding would have to be accepted.

The degree of success achieved at Valcartier would seem sufficient justification for larger scale field trials. Such trials should include the testing of larger size canopy openings, and an investigation into the possibility of an earlier tree kill by the application of poison to the girdle.

The discovery of a substantial difference in seedling height growth on quadrats established one and two years following stand treatment warrants further study. While this phenomenon was of little apparent importance in this study, it might have significant implications elsewhere.

\section{REFERENCES}

ANDERSON, M. L. 1964. Height growth of yellow birch seedlings under various canopy densities. Canada, Dept. of Forestry of Canada, For. Res. Br., Mimeo Report 64-0-2.

BARRETT, J. W., C. E. FARNSWORTH and W. RUTHERFORD Jr. 1962. Logging effects on regeneration and certain aspects of microclimate in northern hardwoods. $J$. Forestry $60(9): 630-639$.

FAYLE, D. C. F. 1961. Treatment to regenerate yellow birch in Ontario (Project H-92). Department of Forestry of Canada, For. Res. Br., Mimeo Report 61-7.

GILBERT, A. M. and V. S. JENSEN, 1958. A management guide for northern hardwoods in New England. U.S. Dept. Agr., Northeast. Forest Exp. Sta. Paper 112.

GODMAN, R. M. 1957. Disking increases the number and growth of yellow birch seedlings. U.S. Dept. Agr., Lake States Forest Exp. Sta., Tech. Note 511.

HOLOWACZ, J. 1960. Progress report on prescribed burning in the hard maple - yellow birch cover type in Ontario, 1958-1959. Ontario Dept. of Lands and Foresrs, Res. Br. Sec. Report (Forestry), No. 37.

JARVIS, J. M. 1956. An ecological approach to tolerant hardwood silviculture. Canada Dept. Northern Affairs and National Resources, For. Res. Div., Tech. Note 43.

1957. Cutting and seedbed preparation to regenerate yellow birch. Canada, Dept. Northern Affairs and National Resources, For. Res. Div., Tech. Note 53.

JENSEN, V. S. 1950. Northern hardwood regeneration studies. U.S. Dept. Agr., Northeast. Forest Exp. Sta., Northern Hardwood Res. Ctr. Quart. Report, March.

LEAK, W. B. and R. W. WILSON, Jr. 1958. Regeneration after cutting of old-growth northern hardwoods in New Hampshire. U.S. Dept. Agr., Northeast. Forest Exp. Sta., Sta. Paper 103.

LINTEAU, A. 1948. Factors affecting germination and early survival of yellow birch in Quebec. For. Chron. 24(1): 27-86.

LOGAN, K. T. 1965. Growth of tree seedlings as affected by light intensity. I. White birch, yellow birch, sugar maple and silver maple. Dept. of Forestry of Canada, Publication No. 1121.

ROWE, J. S. 1959. Forest regions of Canada. Canada, Dept. Northern Affairs and National Resources, For. Br. Bull. 123.

WANG, R. S. P. 1964. Treatment to increase yellow birch regeneration in the tolerant hardwood stands, Goulais River, Ontario. Dept. of Forestry of Canada, For. Res. Br., Mimeo. Report 64-0-15.

ZILLGITT, W. M., and F. H. Eyre. 1945. Perpetuation of yellow birch in Lake States Forests. J. Forestry $43(9): 658-661$. 